\title{
Evaluasi Keberhasilan Program Pertukaran Mahasiswa Inbound Outbound antara Prodi Administrasi Pendidikan FIA UB dan Manajemen Pendidikan FIP Unesa
}

\author{
Azumatul Fajriyah, Balinda Nurul Ainiyah, Choirotun Nadhiroh, Tyas Mawardani \\ azuma88@student.ub.ac.id, choirotun_ndrh@student.ub.ac.id, \\ balindanurulain@student.ub.ac.id, yasmawardani@student.ub.ac.id.
}

\author{
Fakultas Ilmu Administrasi \\ Universitas Brawijaya
}

\begin{abstract}
Abstrak
Evaluasi Keberhasilan Program Pertukaran Mahasiswa inbound outbound antara Prodi Administrasi Pendidikan FIA UB dan Manajemen Pendidikan FIP Unesa. Program tersebut merupakan kegiatan pertukaran pelajar dalam rangka Merdeka Belajar Kampus Merdeka (MBKM) untuk memperluas pengalaman mahasiswa guna dapat merasakan atmosfer akademik yang berbeda dengan mengikuti proses pembelajaran dikampus lain. Penelitian ini ditujukan guna melakukan analisis terhadap keberhasilan program pertukaran mahasiswa serta merekomendasikan upaya perbaikan sebagai evaluasi dari program yang diselenggarakan. Beberapa hal yang keterkaitan evaluasi program ini adalah organisasi pelaksananya, terkait rencanya programnya, dan pengaruhnya terhadap kedua program studi. Hasil Penelitian Evaluasi Keberhasilan Program Pertukaran Mahasiswa inbound outbound antara Prodi Administrasi Pendidikan FIA UB dan Manajemen Pendidikan FIP Unesa ini masih terdapat beberapa kendala yaitu pada proses pelaksanaan kerjasamanya, proses pembelajarannya, dan output atau outcome dari pengukuran evaluasi program.
\end{abstract}

Kata Kunci: Evaluasi program, Keberhasilan program, Pertukaran mahasiswa, Merdeka Belajar Kampus Merdeka

\begin{abstract}
Evaluation of the Success of the inbound outbound Student Exchange Program between the Education Administration Study Program FIA UB and Education Management FIP Unesa. The program is a student exchange activity in order to Merdeka Belajar Kampus Merdeka (MBKM) to enrich student learning experiences at other universities with different academic atmospheres through credit transfer anf credit acquisition. The purpose of this study is to analyze the success of the student exchange program and its improvement efforts as an evaluation of the program being held. Several things related to the evaluation of this program are the implementing organization, related to the program plan, and its impact on the two study programs. The results of the Research Evaluation of the Success of the inbound outbound Student Exchange Program between the Education Administration Study Program of FIA UB and the Education Management of FIP Unesa, there are still several obstacles, namely the process of implementing the collaboration, the learning process, and the output or outcome of the program evaluation measurement.
\end{abstract}

Keywords: Program evaluation, Program success, Student exchange, Merdeka Belajar Kampus Merdeka 
PENDAHULUAN

\section{A. Latar Belakang}

Pasal 13 Undang-undang No 20 Tahun 2003 mengenai Sistem Pendidikan Nasional, terdapat tiga jalur pendidikan. Yang pertama yaitu formal, yang kedua yaitu non formal, yang ketiga adalah informal yang mana ketiganya saling melengkapi. Dalam pelaksanaan pendidikan formal Indonesia pada tahun 2020 mengembangakan sebuah inovasi pendidikan dengan program yang bernama MBKM atau Merdeka Belajar Kampus Merdeka. MBKM menawarkan beberapa program yaitu Magang yang bersertifikat, Pertukaran Mahasiswa Merdeka, Kampus Mengajar, dan Proyek Studi Independen yang juga bersertifikat. Berdasarkan program tersebut, Universitas Negeri Surabaya membuat program pertukaran mahasiswa merdeka dengan mengajak kerjasama Universitas Brawijaya khususnya pada prodi Administrasi Pendidikan Fakultas Ilmu Administrasi. Kegiatan tersebut bernama Program Pertukaran Mahasiswa inbound outbound antara Prodi Administrasi Pendidikan FIA UB dan Manajemen Pendidikan FIP Unesa.

Menurut Rossi, Lipsey, dan Freeman dalam Faza \& Suwitri (2016) terdapat tiga aspek utama dalam teori program. Pertama yaitu organisasi. Kedua yaitu rencana. Ketiga yaitu pengaruhnya. Program dari organisasi pelaksana adalah mengadakan kolaborasi antara dua Fakultas dengan dengan dasar administrasi atau manajemen pendidikan. Kedua Program pendidikan tersebut memiliki atmosfer akademik yang berbeda sehingga akan bermanfaat bagi kedua prodi untuk bertukar pengalaman belajar dalam mengembangkan softskill, kemampuan berkolaborasi, dan adaptif dengan dua lingkungan yang berbeda. Dengan terjalinnya kolaborasi ini, akan lebih baik jika kita menelisik lebih dalam pelaksanaan programnya, kebermanfaatan program, kendala pelaksanaan program, dan evaluasi keberhasilan programnya.

Rodriguez (2019) menyatakan bahwa evaluasi program adalah proses sistematis yang bertujuan untuk memberikan langkah-langkah yang memadai untuk mengevaluasi efektivitas program dengan menggunakan berbagai strategi pengumpulan data. Hal ini menyebabkan evaluasi program sangat penting untuk dilakukan untuk keberhasilan program yang dijalankan sebagai acuan untuk pembanding hasil sebelum pelaksanaan ataupun setelah pelaksanaan. Pertukaran mahasiswa ini 
dilakukan dengan dasar pelaksanaan Merdeka Belajar Kampus Merdeka (MBKM) dengan beberapa tujuan yaitu mahasiswa dapat melakukan komunikasi sosial dengan mahasiswa di kampus lain, mahasiswa mendapatkan pengalaman dari lingkungan sosial kampus lain melalui pembelajaran, mahasiswa dapat meningkatkan kompetensi akademiknya, dan mahasiswa dapat mengembangkan kepemimpinannya, kepercayaan dirinya juga kepekaan sosial.

Dari program tersebut, penulis tertarik untuk mengkaji program pertukaran mahasiswa tersebut untuk mengetahui bagaimana evaluasi dari program yang tekah dilaksanakan dari kedua program studi.

\section{B. Perumusan Masalah}

1. Apakah Keberhasilan program Pertukaran Mahasiswa inbound outbound antara Prodi Adpend FIA UB dan MP FIP Unesa sudah tercapai?

2. Bagaimana upaya untuk melakukan perbaikan terhadap kendala yang dihadapi program Pertukaran Mahasiswa inbound outbound antara Prodi Adpend FIA UB dan MP FIP Unesa?

\section{Tujuan Penelitian}

Tujuan dari penelitian ini adalah sebagai berikut :

1. Menganalisis bagaimana keberhasilan program pertukaran mahasiswa inbound outbound antara Prodi Adpend FIA UB dan MP FIP Unesa sudah tercapai.

2. Menganalisis bagaimana upaya untuk melakukan perbaikan terhadap kendala yang dihadapi program Pertukaran Mahasiswa inbound outbound antara Prodi Adpend FIA UB dan MP FIP Unesa.

\section{D. kerangka Pemikiran Teoritis}

\section{Evaluasi}

Wandt dan Brown dalam Wulan \& Rusdiana (2015) mengemukakan bahwa "evaluation refer to the act or process to determining the value of something" yang berarti evaluasi mengacu pada kegiatan atau rangkaian proses guna menentukan suatu nilai. Evaluasi dikaitkan dengan proses penilaian atau akhir dari penilaian. Berhasil atau tidaknya suatu tujuan atau sebuah program akan terlihat setelah kita melakukan evaluasi terhadap apa yang dihasilkannya. Evaluasi juga merupakan sebuah bagian penting 
dari proses untuk memberikan keputusan selanjutnya terhadap apa yang kita lakukan sekarang.

Kifer dalam Ananda \& Rafida (2017) menyebutkan bahwa evaluasi adalah sebagai penyelidikan dalam menentukan nilai atau manfaat dari suatu produk, prosedur atau proyek, dan program. Evaluasi dapat menentukan atau dapat digunakan sebagai acuan untuk pembanding hasil sebelum pelaksanaan ataupun setelah pelaksanaan. Dengan pendefinisian tersebut evaluasi bisa dirancang dengan menilai untuk meningkatkan manfaat program dari proses evaluasi tersebut.

\section{Evaluasi Program}

Rodriguez

menyatakan bahwa evaluasi program adalah proses sistematis yang bertujuan untuk memberikan langkah-langkah yang memadai untuk mengevaluasi efektivitas program dengan menggunakan berbagai strategi pengumpulan data. Menurut Anderson dan Ball (1978) evaluasi program memiliki enam tujuan utama yang diantaranya sebagai berikut: (a) untuk berkontribusi pada keputusan tentang instalasi program; (b) untuk berkontribusi pada keputusan tentang kelanjutan atau perluasan program; (c) untuk berkontribusi pada keputusan tentang modifikasi program; (d) untuk mendapatkan bukti guna menggalang dukungan bagi suatu program; (e) untuk mendapatkan bukti untuk menggalang oposisi terhadap suatu program; (f) untuk berkontribusi pada pemahaman dasar psikologis, sosial, dan proses lainnya. Menurut Rogers, Kelly, \& McCoy (2019) penggunaan evaluasi dapat diartikulasikan dengan lebih baik dengan menjelajahi hubungan antara mempromosikan penggunaan evaluasi dan konsep literasi evaluasi.

\section{Keberhasilan Program}

Menurut Korten (1988) mengemukakan bahwa terdapat tiga komponen penting yang berkenaan dengan keberhasilan program. Komponen pertama yaitu program atau programme. Komponen kedua yaitu organisasi pelaksanaan program atau organization. Organisasi pelaksana merupakan pihak yang memiliki tanggung jawab melaksanakan program. Komponen terakhir yaitu kelompok sasaran program atau beneficiaries. Apabila ketiga komponem diatas kurang 
diperhatikan dalam suatu program maka program tersebut kemungkinan akan kurang berhasil ataupun mengalami kegagalan

\section{Program}

Menurut Rossi, Lipsey, dan Freeman dalam Faza \& Suwitri (2016) terdapat tiga aspek utama dalam teori program, meliputi: (1) Organisasi pelaksananya. Pada pelaksanaan organisasi, maka pelaksanaannya harus mengalami perubahan yang lebih baik dibandingkan yang sebelumnya. Karena organisasi merupakan kerjasama yang dilakukan dua pihak atau lebih guna meraih tujuan yang disepakati bersama. Dalam pelaksanaan suatu program belum tentu berhasil, akan tetapi bisa juga kurang berhasil dan adapun juga gagal dalam pelaksanaanya. Maka dari itu dalam pelaksanaanya perlu didukung dengan adanya prosedur, kebijaksanaan dan sumber daya sehingga dapat mencapai tujuan sesuai yang diharapkan. (2) Rencana programnya dan pemanfaatan layanannya. Rencana program merupakan suatu proses untuk melakukan sesuatu yang telah direncanakan dengan menggunakan layanan yang tersedia. (3) Pengaruh dari teorinya. Dalam hal ini pengaruh dari teori dapat lebih mengarah kepada sesuatu yang dapat mengalami perubahan untuk menuju arah yang lebih positif.

\section{Program Pendidikan}

Pendidikan menurut UU No. 20 Tahun 2003 tentang SISDIKNAS adalah usaha sadar dan terencana untuk mewujudkan suasana belajar dan proses pembelajaran agar peserta didik secara aktif mengembangkan potensi dirinya untuk memiliki kekuatan spiritual keagamaan,pengendalian diri, kepribadian, kecerdasan, akhlak mulia, serta keterampilan yang diperlukan dirinya, masyarakat bangsa dan negara. Program pendidikan adalah kegiatankegiatan yang akan dilakukan dalam rangka mencapai tujuantujuan pendidikan,sesuai dengan strategi dan kebijakan pendidikan yang telah diterapkan (Ananda, 2016:9).

\section{Pertukaran Mahasiswa Merdeka}

Dalam

Panduan

Pendaftaran Pertukaran Mahasiswa Merdeka (2021) menjelaskan bagaimana pertukaran mahasiswa merdeka itu, penjabarannya adalah 
pertukaran mahasiswa selama satu semester dari klaster daerah ke klaster daerah lainnya yang memberikan pengalaman kebinekaan, mereka menyebutkan juga bahwa sistem alih kreditnya dihitung sebanyak 20 sks dan 2 sks wajib. Pertukaran mahasiswa ini memiliki dua alur yaitu mahasiswa mengambil 20 sks dari mata kuliah yang ditawarkan dan yang kedua adalah mahasiswa dapat mengkombinasikan mata kuliah yang ditawarkan perguruan tinggi penerima.

\section{E. Metode Penelitian}

Dalam penelitian ini penulis menggunakan penelitian kualitatif. Penelitian kualitatif ini menekankan pada analisisnya dengan proses penyimpulan deduktif dan induktif dan juga pada analisis fenomena yang diamati dengan menggunakan logika ilmiah. Dalam penelitian ini penulis mengambil fokus penelitian dalam program pertukaran pelajar antara Administrasi Pendidikan Fakultas Ilmu Administrasi Universitas Brawijaya dengan Manajemen Pendidikan Fakultas Ilmu Pendidikan Universitas Negeri Surabaya. Informan yang ada dalam penelitian ini dengan teknik purposive sampling adalah Dosen
Fakultas Ilmu Pendidikan Universitas Negeri Surabaya dan Dosen Fakultas Ilmu Administrasi Universitas Brawijaya. sedangkan dengan sampling quota yaitu 10 mahasiswa dari 30 mahasiswa yang mengikuti program tersebut. Dalam teknik ini penulis menggunakan teknik pengumpulan data dengan observasi, wawancara, dan dokumentasi. Setelah pemgumpulan data, penulis menggunakan teknik analisis data, pemyajian data, dan menarik kesimpulan.

\section{HASIL PENELITIAN DAN PEMBAHASAN}

\section{A. Evaluasi Keberhasilan Program}

Berdasarkan teori Korten disebutkan bahwa keberhasilan program berkenaan dengan tiga komponen. Komponen pertama yaitu program atau programme. Komponen kedua yaitu organisasi pelaksanaan program atau organization. Komponen terakhir yaitu kelompok sasaran program atau beneficiaries.

\section{Program}

William Dun dalam Damanik dan Marom (2016) mengemukakan lima indikator atau kriteria evaluasi yang mencakup efektivitas, kecukupan, pemerataan, responsivitas, dan ketepatan. Yang pertama, dalam program pertukaran 
mahasiswa inbound outbound antara dua prodi ini kita perlu mengukur pencapaian hasil yang diinginkan untuk mencapai efektivitas pelaksanaan program. Yang kedua, kecukupan dengan seberpa jauh hasil yang telah dicapai untuk mengatasi permasalahan atau kendala. Yang ketiga, pemerataan kepada kedua prodi tersebut terkait manfaat yang diperoleh. Yang ke empat adalah bagaimana responsivitas terhadap hasil dari pencapaian program dan evaluasi yang akan dilakukan. Adapun tujuan dari pelaksanaan program ini adalah belajar lintas kampus agar berkembang dan persaudaraan lintas budaya dan suku semakin kuat, meningkatkan persatuan dan kesatuan, menyelenggarakan transfer ilmu pengetahuan untuk menutupi disparitas pendidikan antar perguruan tinggi. Dari pemaparan tujuan, banyak hal telah terindikasi tercapai namun, ada beberapa kendala yang dapat menghambat pelaksanaannya yaitu terkait perencanaan, indikator program yang harus lebih diperjelas, dan perlu memperhatikan aspek proses, output atau outcome pembelajaran.

Dalam Wahyu, et al (2020) kurikulum ideal mempunyai kesesuaian antara capaian pembelajaran dengan metode dan materi pembelajaran. Seperti halnya dengan program pertukaran mahasiswa inbound outbound ini, kedua program pendidikan harus menjamin lulusannya mempunyai kualifikasi atau kompetensi yang setara dengan kualifikasi yang disepakati dalam Capaian Pembelajaran Lulusan (CPL) mata kuliahnya. Capaian ini seharusnya memiliki indikator yang jelas terkait penyusunan desain pembelajaran, pendekatan pembelajaran, media pembelajaran, metode, strategi pembelajaran, model, dan evaluasi yang sesuai agar tercipta program dengan tingkat keberhasilan yang memuaskan. Pelaksanaan kerjasama program ini, lebih terkesan dirancang dengan perencanaan yang cepat dan tiba-tiba. Walaupun dalam program ini dapat meningkatkan kapabilitas mahasiswa melalui perkuliahan yang lebih mendalam atau mungkin pembelajaran yang tidak tersedia di program studi masing-masing, tetapi tetap harus mengutamakan output yang diterima mahasiswa dan program studi masing-masing. 


\section{Organisasi Pelaksana Program}

Faza \& Suwitri (2016) mengemukakan bahwa aspek yang harus diperhatikan dalam menjalankan keberhasilan evaluasi adalah proses rencana program, pelaksanaan dari program, pelaksanaan sesuai dengan aturan terkait, dan koordinasi dengan pihak yang terkait. Organisasi pelaksana program pertukaran mahasiswa inbound outbound yang dibahas dalam artikel ini yaitu melibatkan dua belah pihak. Kedua pihak tersebut yaitu kedua prodi pada fakultas dari masing-masing universitas. Dengan dilaksanakannya program ini memberikan manfaat bagi organisasi pelaksana. Kedua prodi sebagai organisasi pelaksana dapat saling bertukar pengalaman satu sama lain. Adapun kendala atau permasalahan yang dihadapi kedua belah pihak yaitu kendala sebelum pelaksanaan program, kendala saat pelaksanaan, dan kendala setelah pelaksanaan program. Permasalahan sebelum pelaksanaan adalah kerjasama yang terlalu tiba-tiba dan terkesan perencanaan cepat membuat beberapa mahasiswa harus mengurusi perihal administrasi akademik dan beberapa penyesuaian yang lainnya. Kendala yang dihadapi

saat terlaksananya program adalah proses pembelajaran daring yang membuat kegiatan pertukaran mahasiswa inbound outbound belum maksimal. Hal tersebut bisa dikatakan karena salah satu tujuan dari pelaksanaan program ini adalah belajar lintas kampus agar berkembang dan persaudaraan lintas budaya dan suku semakin kuat, poin tersebut membuat nilai dari program ini belum maksimal. Kendala yang ketiga adalah evaluasi program yang belum terukur.

\section{Kelompok Sasaran Program}

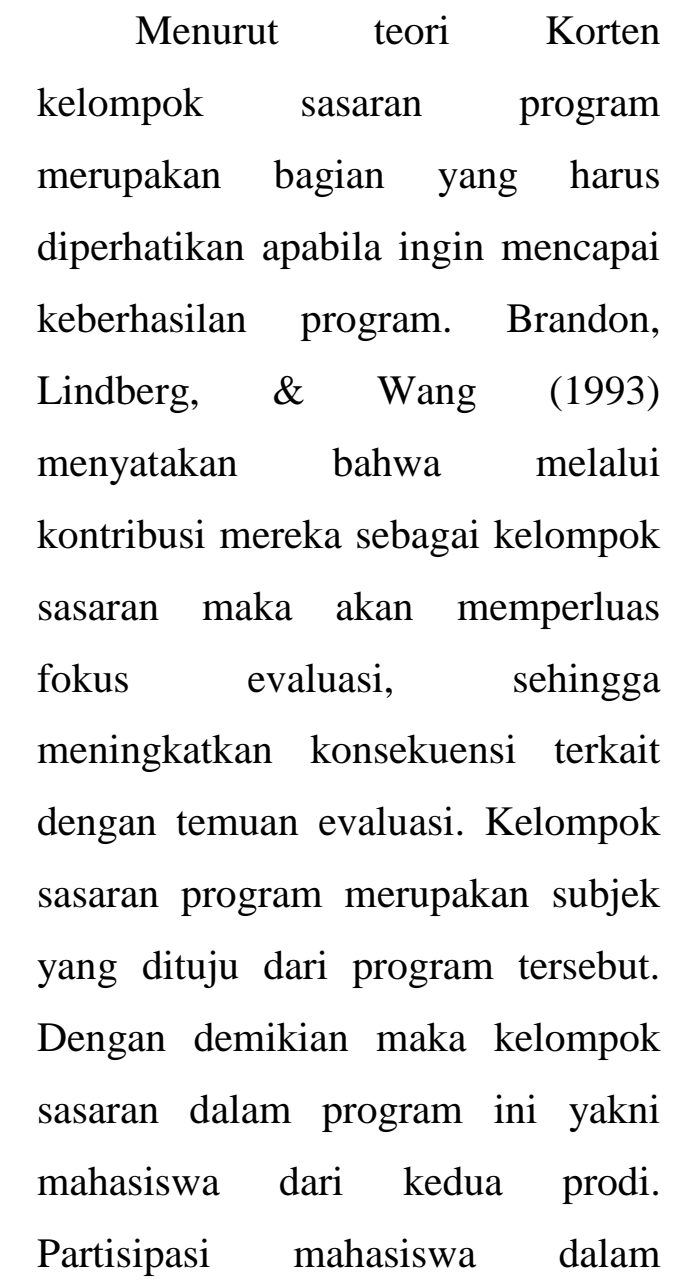


mengikuti program ini mencakup tiga rangkaian.

Pertama, sebelum pelaksanaan program. Tahap ini merupakan tahap yang berkaitan dengan proses administrasi dan persiapan kegiatan. Terkait dengan hal ini, mahasiswa yang berpartisipasi dalam program mengalami beberapa kendala. Berdasarkan wawancara yang dilaksanakan peneliti terhadap mahasiswa yang mengikuti program ini diketahui bahwa kendala tersebut meliputi tiga hal. Kendala pertama yaitu mahasiswa mengalami kesulitan ketika pengisian berkasberkas. Kendala kedua yaitu kurangnya sosialisasi dari prodi terkait dengan program yang akan dilaksanakan. Kendala ketiga yaitu penyesuaian jadwal mata kuliah antara prodi kampus satu dan lainnya.

Kedua, ketika pelaksanaan. Pelaksanaan program berkaitan dengan proses belajar mengajar yang sedang berlangsung. Berdasarkan wawancara yang dilaksanakan peneliti terhadap mahasiswa yang mengikuti program ini diketahui bahwa dalam pelaksanaan program mahasiswa mengalami kendala terkait dengan hal-hal teknis. Kendala yang dihadapi yaitu kuranganya komunikasi antara mahasiswa dari kampus yang satu dengan mahasiswa kampus lainnya, terutama ketika menentukan waktu untuk mengerjakan tugas berkelompok. Hal ini kemudian berdampak pada proses diskusi kelompok yang tidak maksimal dikarenanakan pembagian tugas yang tidak seimbang antara satu mahasiswa dengan yang lainnya.

Ketiga, setelah pelaksanaan program. Dalam hal ini berkaitan dengan hasil atau output yang diperoleh mahasiswa. Output atau hasil disini berkaitan dengan manfaat yang diperoleh mahasiswa setelah mengikuti program. Beberapa manfaat tersebut meliputi beberapa hal seperti: (1) mahasiswa memperoleh relasi baru; Meningkatkan kapabilitas mahasiswa melalui perkuliahan yang mendang yang tidak didapatkan dari program studi tempat mahasiswa berasal; (3) Mengembangkan karakter mahasiswa. Mahasiswa yang bersangkutan akan mampu meningkatkan softskills yang dimiliki, kemampuan kolaborasi, serta memiliki sikap adaptif. 


\section{B. Upaya Perbaikan Keberhasilan}

Program

\section{Proses Pengambilan Keputusan}

\section{Program}

Colakkadioglu \& Celik (2016) mengemukakan bahwa pengambilan keputusan adalah proses kognitif kritis yang diperlukan pada setiap bidang. Proses pengambilan keputusan program dapat ditautkan dengan keputusan organisasi pelaksana terkait dengan berjalannya program. Dalam hal ini organisasi pelaksana termasuk faktor penting yang menjadi penghubung antara program dengan kelompok sasaran diantaranya yaitu sikap pelaksana dalam pelaksanaan program, sikap FIA UB dalam pemilihan kerjasama untuk pertukaran pelajar, sikap FIA UB dalam melakukan program pertukaran mahasiswa. Pengambilan keputusan terkait dengan program organisasi merupakan serangkaian proses yang mana organisasi pelaksana sebagai pemeran utama dalam melakukan program tersebut dengan mengambil sebuah tindakan ataupun keputusan yang berkaitan dengan program.

Berdasarkan teori keberhasilan program dengan tautannya evaluasi keberhasilan program yang mana sikap FIA UB dalam pemilihan kerjasama dan pengelolaan program sesuai dengan pedoman. Akan tetapi proses kerjasama yang dilakukan FIA UB dengan FIP UNESA sangatlah mendadak sehingga banyak terjadi kendala dalam proses pelaksanaannya seperti dalam administrasi tentang pengisian berkas-berkas karena teknik pengisian tidak disosialisasikan dengan matang, penyesuaian jadwal mata kuliah antar matkul kampus satu dan lainnya karena mengingat semua telah memiliki jadwal matkul tersendiri sehingga hal ini sering bertabrakan dan terkadang sulit untuk menyesuaikannya serta proses pembelajaran yang dilakukan oleh pertukaran mahasiswa ini secara online sehingga kegiatan ini tidak dapat dilaksanakan secara maksimal sehingga evaluasi yang didapat dalam pelaksanaan pertukaran mahasiswa ini belum terukur.

\section{Pemantapan Program sebelum} diimplementasikan

Menurut Ananda

(2016) program pendidikan adalah Program pendidikan adalah kegiatan-kegiatan yang akan dilakukan dalam rangka mencapai tujuan-tujuan pendidikan, sesuai dengan strategi dan kebijakan pendidikan yang telah diterapkan. Berdasarkan dari penjelasan tersebut 
bahwa dalam pelaksanaan kegiatan pendidikan yang akan dilaksanakan untuk mencapai tujuan-tujuan pendidikan harus sesuai dengan strategi dan kebijakan pendidikan yang telah diterapkan. Ketika program pendidikan yang dilaksanakan tidak sesuai dengan strategi yang telah diterapkan sebelumnya, maka kegiatan tersebut tidak bisa dikatakan dengan program pendidikan. strategi yang dimaksud adalah strategi yang diterapkan di kedua universitas yang bekerjasama, yang mana adalah prodi Manajemen Pendidikan FIP Unesa dan Administrasi Pendidikan FIA UB.

\section{Berdasarkan hasil penelitian} yang didapatkan bahwa strategi program pendidikan dalam kegiatan ini belum terlaksana sebagaimana mestinya, sehingga keberhasilan program pendidikan belum terlaksana secara maksimal. Proses kerjasama yang terlalu mendadak juga dapat berdamapak pada pencapaian strategi pendidikan, hal ini dikarenakan prosesnya yang terlalu mendadak kemudian penelaaahan program pendidikan pun ikut mendadak seakan memberikan kesan tergesah-gesah dalam pengesahan program yang akan dilaksanakan nantinya.
Menurut Anuradha (2019) perencanaan adalah konsep dasar menciptakan hasil yang baik. Dengan demikian maka diperlukan perencanaan dan persiapan yang sangat matang dan pemantapan program yang dikaji secara detail agar saat implementasinya dapat berjalan sesuai dengan yang diharapkan dan sesuai dengan strategi pendidikan yang telah diterapkan oleh kedua universitas yang bekerjasama. Yang kemudian akan berdampak baik pada saat program dilaksanakan dari awal kegiatan perkuliahan, proses perkuliahan, hingga selesai semester perkuliahan. Sehingga program kegiatan dapat berjalan dengan baik sesuai tujuan kedua belah pihak (universitas).

\section{Pengukuran Indikator Program} diperjelas

Menurut Wahyu, et al (2020) kurikulum yang ideal adalah yang mempunyai kesesuaian antara capaian pembelajaran dengan metode dan materi pembelajaran. Seperti halnya dengan program pertukaran mahasiswa inbound outbound ini, kedua program pendidikan harus menjamin lulusannya mempunyai kualifikasi atau kompetensi yang setara dengan 
kualifikasi yang disepakati dalam Capaian Pembelajaran Lulusan (CPL) mata kuliahnya. Capaian ini seharusnya memiliki indikator yang jelas terkait penyusunan desain pembelajaran, pendekatan pembelajaran, media pembelajaran, metode, strategi pembelajaran, model, dan evaluasi yang sesuai agar tercipta program dengan tingkat keberhasilan yang memuaskan. Menurut Hermawan (2015) indikator merupakan kompetensi dasar secara spesifik yang dapat dijadikan untuk penilaian atas tercapainya hasil pembelajaran dan juga dapat dijadikan sebagai tolok ukur sejauh mana penguasaan siswa terhadap suatu pokok bahasan atau mata pelajaran tertentu. Indikator juga dapat diartikan sebagai pemberi arah dari adanya suatu konsep dan sekaligus ukuran. Sebagai suatu konsep, indikator pendidikan ialah besaran kuantitatif yang bisa dijadikan untuk mengukur proses dan hasil pendidikan atau dampak dari suatu instrumen kebijakan di bidang pendidikan.

Namun berdasarkan hasil penelitian penulis indikator yang digunakan pada saat pembelajaran kurang jelas sehingga saat proses pelaksanaan program berlangsung kurang terarah dan kurang signifikan dengan indikator yang seharusnya digunakan. Pengukuran indikator harus diperjelas dan dimatangkan sebelum program dilaksanakan, serta harus didiskusikan secara seksama dengan kedua belah pihak, baik dari pihak Unesa maupun pihak UB. Hal ini dilakukan karena indikator merupakan hal yang sangat penting dalam proses perkuliahan, indikator sebagai petunjuk arah dalam proses pembelajaran dan pengajaran saat program diberlangsungkan. Penjelasan indikator ini pastinya pengaruh dari pemantapan persiapan pelaksanaan program tersebut, sehingga ketika program sudah siap di segala aspek dan sudah dikoordinasikan dengan baik dengan pihak-pihak yang terlibat, maka kemungkinan kecil indikator yang digunakan nanti tidak sesuai dengan mata kuliah yang akan dilaksanakan di dalam program tersebut.

4. Pertimbangan Capaian Aspek Proses Pembelajaran dan Output/Outcome Pembelajaran (CPL)

Pada aspek proses pembelajaran dan Output/Outcome Pembelajaran (CPL) ada beberapa kendala yang dapat menghambat pelaksanaan yang terkait dengan 
perencanaan, indikator program yang harus lebih jelas dan juga perlu memperhatikan aspek proses, output/outcome pembelajaran. Menurut pendapat Wahyu et al (2020) kurikulum ideal adalah kurikulum yang mempunyai kesesuaian antara capaian pembelajaran dengan metode dan materi pembelajaran. Seperti halnya pada program pertukaran mahasiswa inbound outbound ini. Program pendidikan harus menjamin lulusannya mempunyai kualifikasi atau kompetensi yang setara dengan kualifikasi yang disepakati dalam Capaian Pembelajaran Lulusan (CPL) mata kuliahnya. Capaian ini seharusnya memiliki indikator yang jelas terkait penyusunan desain pembelajaran, pendekatan pembelajaran, media pembelajaran, metode, strategi pembelajaran, model, dan evaluasi yang sesuai agar tercipta program dengan tingkat keberhasilan yang memuaskan.Begitu pula dengan capaian output/outcome pembelajaran pada program ini harus dipertimbangkan dengan baik. Pertimbanga tersebut tentunya melalui diskusi dan koordinasi yang baik antar dua universitas yang bekerjasma, yakni Unesa dan UB.
Pertimbangan capaian output/outcome sangatlah penting untuk dilakukan, hal tersebut dikarenakan akan memberikan dampak yang positif bagi universitas, fakultas, prodi dan terutama mahasiswa itu sendiri. Ketika capaian output/outcome dirancang dengan baik maka proses pembelajaran dan pengajaran akan berjalan dengan baik pula dan tujuan yang diinginkan akan tercapai seperti yang diinginkan.

\section{PENUTUP}

\section{Kesimpulan}

Tiga aspek utama yang dikaji oleh peneliti dalam evaluasi keberhasilan program pertukaran mahasiswa inbound outbound meliputi program, organisasi pelaksana, dan kelompok sasaran. Pertama, terkait dengan aspek program. Pada aspek ini secara keseluruhan program ini masih dikatakan kurang berhasil. Berdasarkan pemaparan tujuan, banyak hal telah terindikasi tercapai. Akan tetapi masih terjadi beberapa kendala yang dapat menghambat pelaksanaan khususnya terkait perencanaan, indikator program, dan aspek proses serta output atau outcome pembelajaran. Kedua, terkait dengan aspek organisasi pelaksana. Pada aspek ini secara keseluruhan dapat 
dikatakan masih belum berhasil. Hal ini dikarenakan dalam proses sebelum pelaksanaan, ketika pelaksanaan, dan setelah pelakaanaan masih kurang matang sehingga berakibat pada munculnya kendala-kendala yang terjadi. Ketiga, terkait dengan aspek kelompok sasaran. Pada aspek ini, setelah pelaksanaan program dapat dikatakan cukup berhasil karena output atau hasil yang diperoleh mahasiswa bersifat positif. Akan tetapi, ketika sebelum pelaksanaan dan proses pelaksanaan program masih kurang berhasil karena adanya kendala yang dialami mahasiswa.

Kendala-kendala yang terjadi pada ketiga komponen diatas berkenaan dengan proses sebelum pelaksanaan, saat pelaksanaan, dan sebelum pelaksanaan. Secara singkat beberapa kendala tersebut dapat peneliti simpulkan sebagai berikut:

1) Koordinasi kedua pihak yang kurang optimal. Pihak yang dimaksud yaitu organisasi pelaksana dan kelompok sasaran atau yang dituju. Organisasi pelaksana yaitu kedua prodi pada fakultas dari masing-masing universitas. Sedangkan kelompok sasaran yaitu mahasiswa dari kedua prodi pada universitas yang berbeda. Bagi prodi, program ini terkesan belum matang dan tibatiba karena kurang cukupnya waktu untuk koordinasi sebelum program dilaksanakan. Bagi mahasiswa, pelaksaanaan program ini (dalam hal ini proses pembelajaran) kurang berjalan efektif karena kerjasama dan komunikasi antar mahasiswa dari kedua universitas masih belum maksimal.

2) Kurangnya sosialisasi mengenai program, kurangnya sosialisasi berdampak pada proses sebelum pelaksanaan program dan ketika pelakasanaan program. Pada saat sebelum pelaksanaan program, hal ini berdampak pada pihak yang dituju yang mana dalam hal ini yaitu mahasiswa. Sebagai pihak yang dituju, mahasiswa mengalami kendala berupa kesulitan ketika pengisian berkas-berkas dikarenakan kurang adanya sosialisasi dari pihak pelaksana.

3) Pelaksanaan program yang masih kurang terarah karena indikatorindikator yang kurang terukur. Pelaksanaan progran berkaitan dengan proses pembelajaran. CPL pada mata kuliah dari program masih kurang matang. Hal ini dikarenakan indikator-indikator yang ingin dicapai pada program ini masih belum terukur. 
Pelaksanaan kerjasama program ini, lebih terkesan dirancang dengan perencanaan yang cepat dan tiba-tiba.

4) Program yang masih belum matang karena tergolong baru. Program kerjasama antara dua prodi ini merupakan program yang masih tergolong baru. Progran ini kemungkinan akan berlanjut pada semester dan tahun berikutnya, oleh sebab itu diperlukan evaluasi agar indikator-indikator pencapaian tujuan dalam program ini lebih terukur. Aspek penting yang harus diperhatikan terkait dengan evaluasi ini yaitu asspek proses pembelajaran dan output/outcome pembelajaran (CPL).

\section{Saran}

Dari kesimpulan yang telah dipaparkan diatas mengenai evaluasi keberhasilan program pertukaran mahasiswa inbound outbound antara prodi Administrasi Pendidikan FIA UB dan Manajemen Pendidikan FIP Unesa penulis dapat memberikan saran sebagai berikut:

1) Koordinasi yang baik antara pihak Unesa dengan pihak UB, pihak yang dimaksud adalah baik dari universitas, fakultas dan prodi maupun dari pihak dosesn dan mahasiswanya, jika koordinasi diatara pihak-pihak tersebut dikomunikasikan dengan baik maka akan sangat mempermudah pelaksanaan program tersebut. Koordinasi dilakukan di seluruh aspek yang dapat mempengaruhi berlangsungnya program pendidikan yang akan dilakukan, pengelolaan program yang baik, dan kelanjutan program tersebut di masa depan, hal ini dikarenakan pelaksanaan program saat ini akan sangat mempengaruhi pelaksanaan di masa yang akan datang, serta koordinasi yang baik ini juga dapat memperkecil celah akan terjadinya kendala dan hal yang tidak diharapkan saat pelaksaaan program.

2) Sosialisasi mengenai program pendidikan kepada mahasiswa maupun dosen secara umun baik di prodi Manajemen Pendidikan FIP Unesa maupun di prodi Administrasi Pendidikan FIA UB. Sosialisasi yang dimaksud adalah segala aspek yang akan berkaitan dengan pelaksanaan program. Mulai dari penjelasan program apa yang akan mereka ikuti nantinya, teknik pendaftaran jika ingin mengikuti program, tentang 
bagaimana sistem pelaksaannya, penyesuaian jadwal antara mahasiswa MP FIP Unesa dengan AP FIA UB. Hal tersebut dilakukan tentunyan agar ketika proses pelaksanaan berlangsung bisa lancar sesuai dengan apa yang diharapkan, serta agar tidak menghambat proses berlangsungnya pelaksanaan program, apabila mahasiswa belum memahami program seperti apa yang sedang mereka jalani, maka proses pengajaran dan pembelajaran menjadi terhambat. Dengan adanya sosialisasi tersebut diharapkan baik dosen dan terutama mahasiswa dapat memahami betul program apa yang sedang dilaksanakan serta supaya tujuan-tujuan pendidikan melalui program tersebut dapat tercapai sebagaimana mestinya.

3) Pemantauan berkala harus dilakukan agar program pendidikan yang sedang dilaksanakan dapat berjalan dengan lancar dan selalu dalam jalur dan selalu terarah seperti yang telah direncanakan. selai itu pemantauan berkala juag sangan berguna ketika program pendidikan memiliki kendala disaat proses pelaksanaan program berlangsung, seperti kurang jelasnya indikator yang digunakan, atau disaat pelaksanaan program tidak sesuai jalus yang telah di rencanakan dan disepakati oleh kedua belah pihak. Pemantauan berkala bisa dilakukan oleh kedua belah pihak dan dikoordinasikan dengan baik. Kedua universitas harus bekerjasama dengan baik pada saat pemantauan berlangsung agar program pendidikan dapat berjalam dengan baik sebagaimana mestinya. Pemantauan berkala juga akan sangat membantu ketika saat digunkaan untuk bahan evaluasi di projek/ program pendidikan selanjutnya di masa yang akan datang.

4) Menerima saran kritik mahasiswa dan dosen pengajar juga sangat diperlukan pada program ini, mengingat pihak yang terlibat secara intensive adalah mahasiswa dan dosen pengajar. Selain itu program ini tergolong masih baru, dimana program ini adalah pertama kalinya bagi Unesa dan UB dalam bekerjasama di prodi MP FIP Unesa dan di prodi AP FIA UB yang kemungkinan akan berlanjut projek/semester/tahun berikutnya, sehingga masih diperlukan banyak evaluasi dan penyesuaian dalam pelaksanaannya, oleh karenanya 
kritik dan saran dari dosen dan mahasiswa diperlukan untuk membangun dan memperbaiki segala hal yang memang dirasa belum sesuai dengan tujuan program pendidikan yang ingin dicapai dan segala hal yang tidak sesuai dengan apa yang telah disepakati oleh kedua belah pihak (universitas). Diharapkan dengan adanya penerimaan saran dan kritik dosen dan mahasiswa yang terlibat ini bisa membuat program pendidikannya menjadi lebih baik kedepannya.

\section{DAFTAR PUSTAKA}

Ananda, R., \& Rafida, T. (2017). Pengantar evaluasi program pendidikan. Cv. Pusdikra Mitra Jaya. Ananda, R. \& Rafida, T. 2017. Pengantar Evaluasi Program Pendidikan. Medan: Perdana Publishing.

Anderson, S.B., \& Ball S. (1978). The Profession and Practice of Program Evaluation. San Francisco California: Jossey-Bass.

Anuradha, P. (2019). The Teaching Learning Process. International Journal of Advanced Science and Technology, 28(17), 709 - 714.

Brandon, P.R., Lindberg, M.A., \& Wang, Z. (1993). Involving Program
Beneficiaries in the Early Stages of Evaluation: Issues of Consequential Validity and Influence. Educational Evaluation and Policy Analysis Winter 1993, 15( 4), 420428.

Colakkadioglu, O. \& Celik, D.B. (2016). The Effect of Decision-Making Skill Training Programs on Self-Esteem and Decision-Making Styles. Eurasian Journal of Educational Research, 65, 259-276.

Elis Ratna Wulan, E., \& Rusdiana, A. (2015). Evaluasi pembelajaran.

Faza, I. T., \& Suwitri, S. (2016). Evaluasi Kerberhasilan Program Penyediaan Air Minum dan Sanitasi Berbasis Masyarakat (PAMSIMAS) di Kabupaten Tegal (Kajian Peraturan Bupati No. 50 Tahun 2010 Tentang Petunjuk Pelaksanaan Bantuan Program Penyediaan Air Minum dan Sanitasi Berbasis Masyarakat. Journal of Public Policy and Management Review, $1(1), 35-50$.

Hermawan, D., \& Kintamani, I. (2015). Kinerja Pendidikan Anak Usia Dini dan Pendidikan Nonformal Berdasarkan Misi Pendidikan. Jurnal Pendidikan Dan Kebudayaan, 21(1), 87-100. 
Korten, D.C. (1988). Pembangunan Berdimensi Kerakyatan. Jakarta : Yayasan Obor Indonesia.

Rodríguez, N.G. (2019). Evaluation Approaches for Teaching English as a Foreign Language (TEFL) Preparation Program. MEXTESOL Journal, 43(1).

Rogers, A., Kelly, L.M. \& McCoy, A. (2019). Evaluation Literacy: Perspectives of Internal Evaluators in Non-Government OrganizationsCanadian Journal of Program Evaluation, 34(1), 1-26.

Tim Pertukaran Mahasiswa Merdeka. (2021). Evaluation Literacy: Perspectives of Internal Evaluators in Non-Government Organizations Panduan Pendaftaran Pertukaran Mahasiswa
Merdeka. http://dikti.kemdikbud.g o.id/wp-

content/uploads/2021/07/Panduan-

$\underline{\text { Pendaftaran-Pertukaran-Mahasiswa- }}$ Merdeka.pdf

UU RI No. 20 Tahun 2003 tentang Sistem Pendidikan Nasional.

Muhaimin, Suti'ah, dan Sugeng Listyo Prabowo, 2009, Manajemen Pendidikan, Jakarta:Kencana, h. 349 Wahyu, T. A., Lufthansa, L., \& Setiani, P. P. (2020, November). Analisis Kesesuaian Materi dengan Capaian Pembelajaran Lulusan pada Matakuliah Desain dan Strategi Pembelajaran. In Prosiding Seminar Nasional IKIP Budi Utomo (Vol. 1, No. 01, pp. 524-528). 